\title{
Construction and expression of indonesian hepatitis B core antigen (HBcAg) in Lactococcus lactis as potential therapeutic vaccine
}

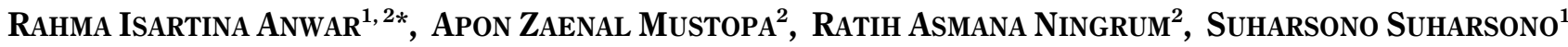 \\ ${ }^{1}$ Bogor Agricultural University, Bogor, Indonesia \\ ${ }^{2}$ Indonesian Institute of Science (LIPI), Jakarta, Indonesia
}

\begin{abstract}
The hepatitis $\mathrm{B}$ core antigen protein $(\mathrm{HBcAg})$ may induce proliferation of $\mathrm{B}, \mathrm{T}$, and cytotoxic $\mathrm{T}$ cells; induce immune responses; and provide T-cell resources for antibody responses after vaccination (Freivalds et al., 2011). Thus, HBcAg may be used as a therapeutic vaccine in patients with chronic hepatitis B virus (HBV) infection. This article describes a study on the construction and expression of HBcAg in Lactococcus lactis by the nisin-controlled expression (NICE) system. An HBcAg gene, the HBV subgenotype B3 that is dominant in Indonesia, was successfully cloned into a pNZ8148 vector and resulted in the formation of the transformant $L$. lactis NZ3900 pNZ818-HBcAg. The HBcAg protein measured $21 \mathrm{kDa}$. Induction with $10 \mathrm{ng} / \mathrm{ml}$ nisin significantly increased the concentration of the expressed protein. Western blotting and dot blot hybridization analysis indicated that the $\mathrm{HBcAg}$ proteins confirmed the expression of an antibody, with potential to become an HBV therapeutic vaccine.
\end{abstract}

Key words: hepatitis B virus, HBcAg gene, Lactococcus lactis, NICE system

\section{Introduction}

The HBV belongs to the Hepadnaviridae family; it is a small, enveloped DNA virus that replicates via reverse transcription (Azizi et al., 2000). Nine HBV genotypes have been identified and classified as A, B, C, D, E, F, G, $\mathrm{H}$, and $\mathrm{J}$; the existence of I remains controversial (Utsumi et al., 2009). The HBV sequence is characterized by $8 \%$ and $4-8 \%$ differences in nucleotide (nt) sequences among the genotypes and the subgenotypes, respectively (Lusida et al., 2008). Globally, HBV infections constitute a major health problem, and has two stages: acute and chronic. A World Health Organization (WHO) report indicates over 257 million people have chronic HBV infection (WHO, 2015). Although high virus levels have been reported after treatment with antiviral drugs in chronic HBV infection (Bertoletti and Ferrari, 2012; Buchmann et al., 2013), they continue to be used. Despite their limited long-term therapeutic efficacy and adverse effects, antiviral drugs are incapable of eradicating the covalently closed circular DNA (cccDNA) of HBV and cannot restore immunity. Consequently, HBV replication and hepatic damage resume when antiviral pharmacotherapy ceases (Buhmann et al., 2013). There is a need for therapeutic vaccines to induce strong immunity against HBV infections, particularly in chronic infections. Maini et al. (2000) found that patients with chronic HBV infection with controllable HBV replication levels have noticeably higher levels of the hepatitis B core antigen protein ( $\mathrm{HBcAg}$ ) compared to patients with HBV replication levels that are refractory to treatment. $\mathrm{HBcAg}$ is encoded in the HBV genome $(3.5 \mathrm{~kb}, 22 \mathrm{kDa})$ together with a viral nucleocapsid protein, has an icosahedral conformation, and forms two spherical shells that form small and large capsids with 180 and 240 copies of core protein, respectively (Wingfield et al., 1995). Chisari and Ferrari (1995) reported that HBcAg can induce the proliferation of $\mathrm{B}, \mathrm{T}$, and cytotoxic $\mathrm{T}$ cells in patients with $\mathrm{HBV}$ infection. Moreover, $\mathrm{HBcAg}$ can induce immune

\footnotetext{
* Corresponding author: ${ }^{1}$ Bogor Agricultural University, Bogor, Indonesia; ${ }^{2}$ Indonesian Institute of Science (LIPI), Jakarta, Indonesia; e-mail: isartina@gmail.com
} 
responses and T-cell proliferation after vaccination (Freivalds et al., 2011).

Given the importance of $\mathrm{HBcAg}$ as a therapeutic vaccine, $\mathrm{HBcAg}$ production has been investigated in several expression systems. The expression of recombinant HBcAg in Escherichia coli has been induced through a pFP15 vector under a tryptophan promoter, followed by purification with $30 \%$ ammonium sulfate and a Q-Sepharose Fast Flow Column (Azizi et al., 2000). However, further analyses revealed the presence of inclusion bodies formed by the long peptides of 26 amino acids present at the N-terminus region of $\mathrm{HBcAg}$. Rolland et al. (2011) reported the expression and purification of recombinant HBcAg in Pichia pastoris expressed under an alcohol oxidase gene promoter. The yield of the expressed protein was high, but the process required many days of yeast culture growth under methanol induction.

We report a novel method for the construction and expression of HBcAg Lactococcus lactis NZ3900 by the NICE system. As L. lactis is known to be non-hazardous, it is considered safe for use in the biopharmaceutical development and mucosal administration of $L$. lactis live recombinant therapeutic vaccines (Bermudez et al., 2011). Lactococcus lactis does not contain endotoxins in the membrane; therefore, it is a safe agent to secrete recombinant proteins into growth medium (Jorgensen et al., 2014). Several advantages support the use of $L$. lactis as protein expression host strain - for instance, the efficacy of transformation, the existence of a strong promoter, the small size of its genome, rapid bacterial growth, and, importantly, the fact that the secreted proteins do not form inclusion bodies. We used the HBV subgenotype $\mathrm{B} 3$ of the $\mathrm{HBcAg}$ gene that is dominant in Indonesia. This HBV subgenotype B3 is commonest, followed by HBV/C1, in Indonesia; however, diverse novel genotypes have been isolated (Heriyanto et al., 2012). We aimed to develop an expression system for a therapeutic $\mathrm{HBV}$ vaccine with the $\mathrm{HBcAg}$ gene constructed in a pNZ8148 expression vector and transformed into NZ3900 L. lactis.

\section{Materials and methods}

\section{Bacterial strains, plasmids, and culture conditions}

The bacterial strains and vectors used in this study are listed in Table 1 . The $E$. coli strains were cultivated in Luria-Bertani (LB) medium with aeration at $37^{\circ} \mathrm{C}$, whereas the L. lactis NZ3900 strains were cultivated at $30^{\circ} \mathrm{C}$, without shaking, in M17 media (Himedia) with $0.5 \%$ glucose.

\section{Vector constructions}

The HBcAg gene used in this research was a 549 bplong synthetic gene of the 1839 Java isolate of HBV (GenBank EF473972.1). An 81 bp-long signal peptide ( $\mathrm{SP}_{\text {usp } 45}$; GenBank M60178.1) was added to the genecoding sequence and inserted into the pMAT vector. The recombinant pMAT-HBcAg vector was digested with restriction endonucleases $N c o 1$ and $X b a 1$ (BioLabs $\left.\mathrm{Inc}^{\mathrm{TM}}\right)$. The excised fragment was purified using a DNA Purification Kit (Qiagen) and ligated into the pNZ8148 vector; then, the recombinant vector (pNZ8148-HBcAg) was inserted into the $E$. coli MC1061 strain. Transformants were selected on agar-containing chloramphenicol $\left(\right.$ Sigma $\left.^{\mathrm{TM}}\right)$, and the length of the insert was verified using PnisA_F ( $5^{\prime}$ - TTC CCT CGA GGG ATC TAG TCT TAT AAC- $\left.3^{\prime}\right)$ and TpNZ8148_R (5'-GCT AAA ACG TCT CAG AAA CG $-3^{\prime}$ ) primers. PCR amplification was done as follows: pre-denaturation at $94^{\circ} \mathrm{C}$ for $3 \mathrm{~min}, 35$ cycles of denaturation at $94^{\circ} \mathrm{C}$ for $1 \mathrm{~min}$, annealing at $55^{\circ} \mathrm{C}$ for $1 \mathrm{~min}$, elongation at $72^{\circ} \mathrm{C}$ for $30 \mathrm{~s}$, followed by a final elongation at $72^{\circ} \mathrm{C}$ for $6 \mathrm{~min}$.

\section{Transformation of L. lactis}

The recombinant pNZ8148-HBcAg vector was inserted into L. lactis NZ3900 by using the electroporation method. The $L$. lactis culture was grown overnight in M17 media containing $0.5 \%(\mathrm{wt} / \mathrm{vol})$ glucose, and then was transferred into M17 media containing $0.5 \%(\mathrm{wt} / \mathrm{v})$ glucose, $0.5 \mathrm{M}$ sucrose, and $2.5 \%$ (wt/v) glycine. Culture growth was continued until the optical density of the medium at $600 \mathrm{~nm}\left(\mathrm{OD}_{600}\right)$ reached $\sim 0.3$. Subsequently, cells were collected by centrifugation at $6,000 \times g$ and $4{ }^{\circ} \mathrm{C}$ for $10 \mathrm{~min}$, before resuspension in a cold buffer composed of $0.5 \mathrm{M}$ sucrose and $10 \%(\mathrm{v} / \mathrm{v})$ glycerol. This procedure was repeated with the same buffer, but with the addition of $0.05 \mathrm{M}$ EDTA. Thereafter, the recombinant $\mathrm{pNZ} 8148-\mathrm{HBcAg}$ vector was added to the cell suspension and the mixture was electroporated at $2000 \mathrm{~V}$, $25 \mu \mathrm{F}$, and $260 \Omega$. After electroporation, the cells were transferred directly into recovery medium (M17 containing $0.5 \%(\mathrm{wt} / \mathrm{v})$ glucose) and incubated at $30^{\circ} \mathrm{C}$ for $3 \mathrm{~h}$, without shaking. The cells were then transferred onto M17 agar to which $10 \mu \mathrm{g} / \mathrm{ml}$ chloramphenicol was 
Table 1. Bacterial strains and vectors used in the study

\begin{tabular}{|c|c|c|}
\hline Strains and vector & Characteristics & Source \\
\hline \multicolumn{3}{|l|}{ Bacterial strains } \\
\hline Escherichia coli Top 10 & cloning host strain & Novagen \\
\hline Escherichia coli MC 1061 & cloning host strain & NICE \\
\hline Lactococcus lactis NZ3900 & expression host strain $\mathrm{HBcAg}$ & NICE \\
\hline \multicolumn{3}{|l|}{ Vectors } \\
\hline pMAT & $A m p^{r}$, cloning vector & Invitrogen \\
\hline pNZ8148 & $\mathrm{Cmp}^{\mathrm{r}}$ nisin-inducible promoter & NICE \\
\hline
\end{tabular}

$\mathrm{Amp}^{\mathrm{r}}$ - ampicillin resistance; $\mathrm{Cmp}^{\mathrm{r}}-$ chloramphenicol resistance

added (Holo and Nes, 1995). The transformants were screened for the presence of an insert using PCR (PnisA_F and TpNZ8148_R primers) and Nco 1 and $X b a 1$ restriction enzymes (BioLabs Inc ${ }^{\mathrm{TM}}$ ). The sequence of the construct was verified through sequencing using the Sanger method.

\section{Expression of HBcAg gene in L. lactis NZ390O on transcription level}

Total RNA isolation was undertaken using the TRIzol method (Rio et al., 2010). First, $10 \mathrm{ml}$ of the culture with L. lactis carrying the $\mathrm{pNZ} 8148-\mathrm{HBcAg}$ vector was added to M17 medium supplemented with $0.5 \%$ glucose and $10 \mu \mathrm{g} / \mathrm{ml}$ chloramphenicol. Next, the culture was incubated at $30^{\circ} \mathrm{C}$ until the $\mathrm{OD}_{600}$ of the medium reached 0.4-0.5; at this point, protein production was induced with nisin $(5,10$, and $50 \mathrm{ng} / \mathrm{ml})$. Uninduced bacteria were used as a control; the L. lactis NZ3900 culture was additionally used as another negative control. The bacterial culture was transferred to a $10 \mathrm{ml}$ tube and centrifuged at $13000 \mathrm{rpm}$ for $10 \mathrm{~min}$ at $4{ }^{\circ} \mathrm{C} ; 1 \mathrm{ml}$ TRIzol was added to the cell pellet, which was then resuspended before the addition of $200 \mu \mathrm{l}$ cold chloroform. Lysis was induced by vortexing for $1 \mathrm{~min}$, followed by incubation on ice for $15 \mathrm{~min}$. The mixture was transferred to a new tube and centrifuged at $12000 \mathrm{rpm}$ for $15 \mathrm{~min}$ at $4^{\circ} \mathrm{C}$. The top layer was then transferred into a fresh tube, $500 \mu \mathrm{l}$ cold isopropanol was added, the mixture was thoroughly vortexed for $30 \mathrm{sec}$, and incubated for $1 \mathrm{~h}$ at $-20^{\circ} \mathrm{C}$. After incubation, the mixture were centrifuged at $12000 \mathrm{rpm}$ for $10 \mathrm{~min}$ at $4{ }^{\circ} \mathrm{C}$ to sediment the RNA. The RNA was washed by adding $70 \%$ ethanol and centrifuging the pellet again at $9000 \mathrm{rpm}$ for $10 \mathrm{~min}$ at $4^{\circ} \mathrm{C}$.
The pellet was dried overnight on a laboratory bench before being dissolved in Diethylpyrocarbonate (DEPC)treated $\mathrm{ddH}_{2} \mathrm{O}$ and incubated at $37^{\circ} \mathrm{C}$ for $30 \mathrm{~min}$. Subsequently, RNA was quantified by using a spectrometer at $260 \mathrm{~nm}$.

A one-step RT-PCR kit (Bioline) was used to reverse transcribe total RNA to cDNA. We used $0.1 \mu \mathrm{g}$ total RNA; the reverse transcription mix contained $5 \mu \mathrm{l}$ MyTaq OneStep Mix, $0.1 \mu \mathrm{l}$ reverse transcriptase, $0.2 \mu \mathrm{l}$ RiboSafe RNase Inhibitor, and $3.3 \mu \mathrm{DEPC}$. To amplify $\mathrm{HBcAg}$ cDNA, $400 \mathrm{nM}$ each of the primers HBcAgBamHIHindIII-F (5' - ATTTGGATCCATGGACATTGACCCGT AT $\left.-3^{\prime}\right)$ and HBcAgBamHI-HindIII-R (5' TCTAACAATGAGAATCCCG- $3^{\prime}$ ) were used. Reverse transcription was undertaken at $45^{\circ} \mathrm{C}$ for $30 \mathrm{~min}$. Thereafter, cDNA amplification was conducted as follows: 5 min of predenaturation at $94^{\circ} \mathrm{C}$, denaturation at $94^{\circ} \mathrm{C}$ for $1 \mathrm{~min}$, annealing for $1 \mathrm{~min}$ at $50^{\circ} \mathrm{C}$ and elongation for 3 min at $72^{\circ} \mathrm{C}$ for 35 cycles, followed by a final elongation for 3 min at $7^{\circ} \mathrm{C}$. Agarose electrophoresis was carried out to visualize $\mathrm{PCR}$ products using $0.5 \mu \mathrm{g} / \mathrm{ml}$ ethidium bromide.

Quantitative PCR (qPCR) analysis was conducted according to the protocol by Schmittgen dan Livak (2008). The first step of qPCR was a standard curve formulation using for $16 \mathrm{~S}$ rRNA. cDNA were diluted to final concentrations of $0.2,0.02$, and $0.002 \mathrm{ng} / \mu \mathrm{l}$; then, the remaining qPCR reagents were added: $5 \mu$ SYBR qPCR mixture, $300 \mathrm{nM} 16 \mathrm{~S}$ rRNA F primer, $300 \mathrm{nM}$ 16S rRNA R primer, $0.2 \mu \mathrm{l} 50 \times \mathrm{ROX}$ Refer, and $\mathrm{ddH}_{2} \mathrm{O}$ added to a final volume of $50 \mu \mathrm{l}$. The PCR was set as follows: predenaturation at $94^{\circ} \mathrm{C}$ for $5 \mathrm{~min}, 35$ cycles of denaturation at $94^{\circ} \mathrm{C}$ for $1 \mathrm{~min}$, and annealing at $50^{\circ} \mathrm{C}$ for $1 \mathrm{~min}$. 
Next, levels of HBcAg mRNA were measured in samples induced with $0,5,10$, and $50 \mathrm{ng} / \mathrm{ml}$ nisin using the $\mathrm{qPCR}$ method.

\section{Expression of HBcAg gene in L. lactis NZ3900 and partial purification with size-exclusion chromatography (SEC)}

Protein expression was undertaken according to modified Le Loir and Rajalingam methods (Le Loir et al., 1998; Rajalingam et al., 2009). Recombinant L. lactis NZ3900 pNZ8148-HBcAg were cultivated in M17 media to which $0.5 \%$ glucose and $10 \mu \mathrm{g} / \mathrm{ml}$ chloramphenicol were added. Protein expression in recombinants was induced with either 5,10 , or $50 \mathrm{ng} / \mathrm{ml}$ nisin (Sigma-Aldrich). The supernatant was harvested by 30 -min centrifugation at $10000 \mathrm{rpm}\left(4^{\circ} \mathrm{C}\right)$, and precipitated overnight at $4{ }^{\circ} \mathrm{C}$ using $45 \%(\mathrm{wt} / \mathrm{v})$ ammonium persulfate. The protein pellet was harvested through centrifugation and resuspended in $50 \mathrm{mM}$ Tris $\mathrm{HCl}$. Purification with SEC was undertaken as described by Hong et al. (2012). Protein samples were loaded onto a pre-equilibrated Sephadex G-50 pre-packed column (GE Healthcare ${ }^{\mathrm{TM}}$ ), and elution was carried out using $50 \mathrm{mM}$ Tris $\mathrm{HCl}(\mathrm{pH} 7.8)$ with a $0.1 \mathrm{ml} / \mathrm{min}$ flow rate. Sample fractions were collected every $5 \mathrm{~min}$ and analyzed using a spectrophotometer at $280 \mathrm{~nm}$. Additionally, protein fractions were analyzed on $12 \%$ SDS-PAGE and stained by a silver staining kit (Thermo Scientific). The concentration of total proteins was determined using the BCA Protein Assay Kit (Thermo Scientific, USA) according to manufacturer instructions.

\section{Western blotting and dot blot hybridization assays}

Western blotting and dot blot hybridization assays were conducted in accordance with protocols by Sambrook and Russell (Sambrook and Russell, 2001). In Western blotting, protein fractions were electrophoresed on $12 \%$ SDS-PAGE, followed by the transfer of proteins onto a nitrocellulose membrane. The membrane was blocked with $10 \%$ skimmed milk in $1 \times$ Tris Borate EDTA (TBE) for $1 \mathrm{~h}$, rinsed with $1 \times$ Tris Borate EDTA (TBE) $-0.1 \%$ Tween, incubated with the HBcAg Primary Monoclonal Antibody (dilution 1:1000; cat. no. MA1-7608, ThermoFisher Scientific-) and then with secondary antiIg G Mouse Alkaline Phosphatase Conjugates antibody (cat. no. WP20006, ThermoFisher Scientific), before it was stained with 5-bromo-4-chloro-3-indolylphosphate/ nitro blue tetrazolium (BICP/NBT; SigmaFast $\left.{ }^{\mathrm{TM}}\right)$. In the
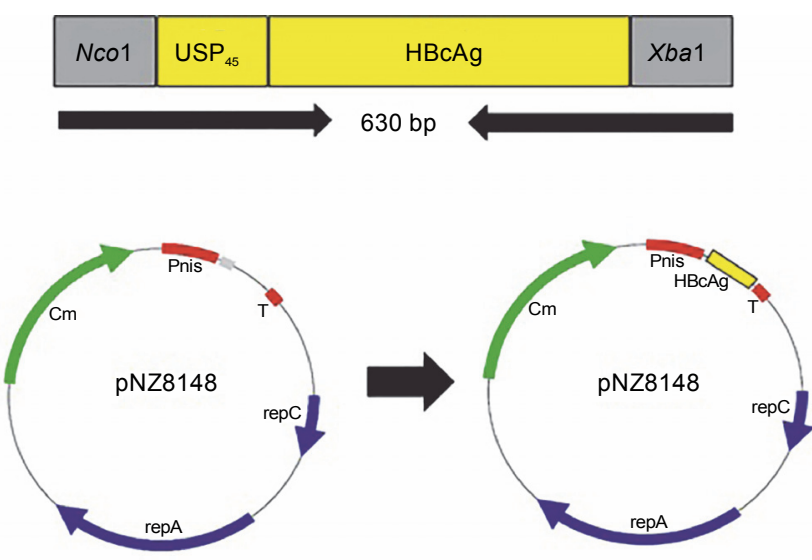

Fig. 1. The construction of the pNZ8148-HBcAg expression vector. The fusion of the $\mathrm{SP}_{u s p 45} \mathrm{HBcAg}$ gene was ligated into the expression vector $\mathrm{pNZ} 8148$

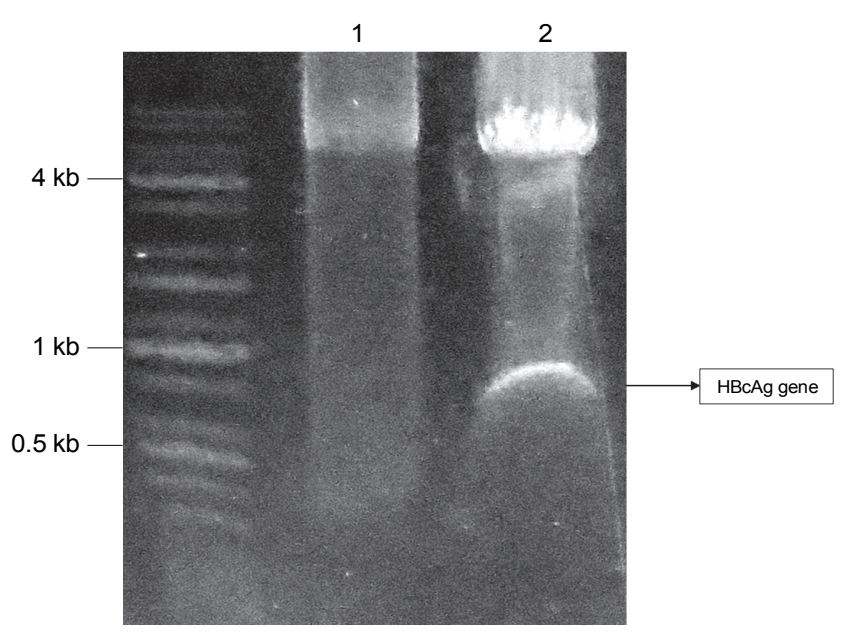

Fig. 2. Analysis ofaDNA construct pNZ8148-HBcAg using Nco1 and $X b a 1$ restriction enzymes: visualization of a DNA vector and target $\mathrm{HBcAg}$ gene using ethidium bromide staining of agarose gel; lane 1 - undigested sample; lane 2 - digested sample

dot blot hybridization assay, proteins were transferred onto a nitrocellulose membrane and then detected using Western blotting analysis as previously described.

\section{Results}

\section{Construction of recombinant vector}

The full-length HBcAg gene encoding the HBcAg protein that we used in this study belonged to the HBV B3 subgenotype - an Indonesian 1839 Java isolate of HBV. Figure 1 presents a construction map of the expression vector harboring the $\mathrm{HBcAg}$ gene. The $\mathrm{HBcAg}$ gene was inserted into the multicloning site of the pNZ8148 expression vector to generate a recombinant pNZ8148- 


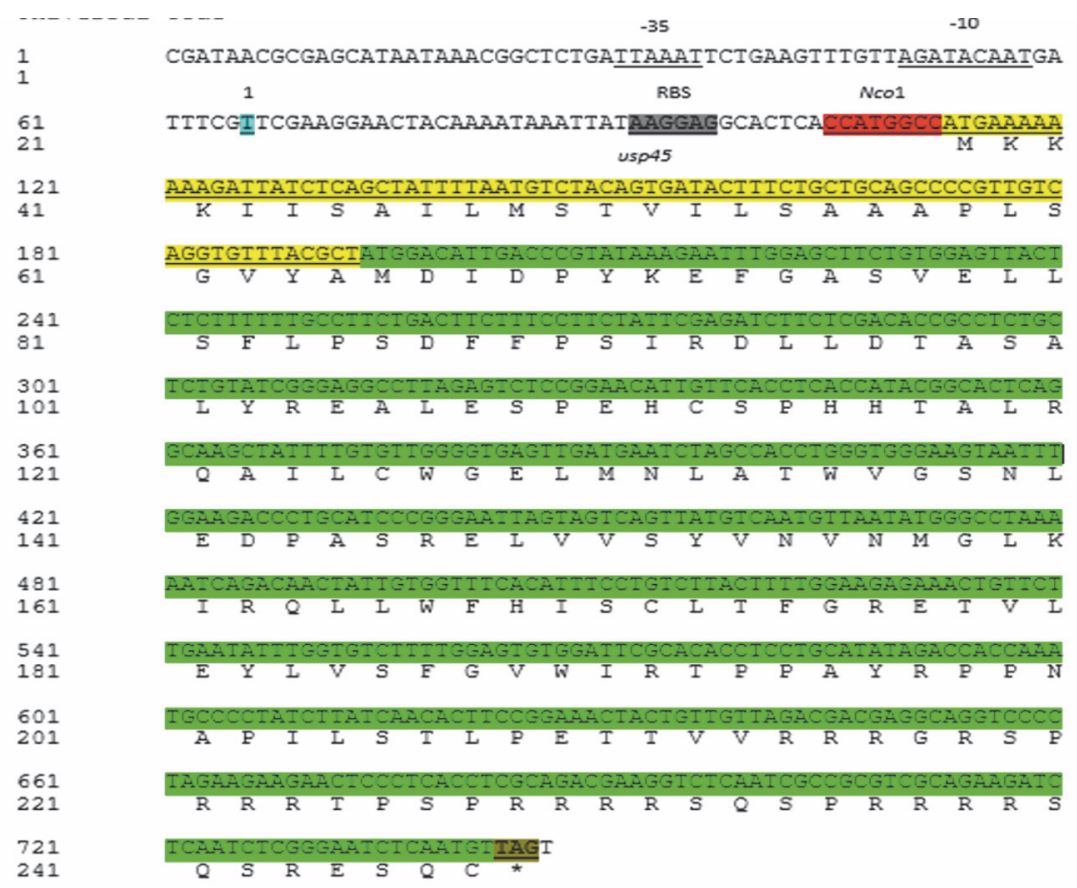

Fig. 3. Sequence analysis of the final $\mathrm{HBcAg}$ construct. RBS is the ribosomebinding site; * stop codon; marked in blue: +1 ; transcription start position, in yellow; $\mathrm{SP}_{u s p 45}$, in green; $\mathrm{HBcAg}$ gene-coding sequence

Table 2. Concentration of cDNA from L. lactis pNZ8148-HBcAg

\begin{tabular}{l|c}
\hline \multicolumn{1}{c|}{ Sample } & $\begin{array}{c}\text { cDNA concentration } \\
{[\mathrm{ng} / \mu \mathrm{l}]}\end{array}$ \\
\hline HBcAg uninduced & 442 \\
\hline $\mathrm{HBcAg}$ induced $5 \mathrm{ng} / \mathrm{ml}$ of nisin & 527 \\
\hline $\mathrm{HBcAg}$ induced $10 \mathrm{ng} / \mathrm{ml}$ of nisin & 544 \\
\hline HBcAg induced $50 \mathrm{ng} / \mathrm{ml}$ of nisin & 578 \\
\hline
\end{tabular}

Table 3. $\Delta \mathrm{C}_{\mathrm{T}}$ of uninduced and induced of L. lactis $\mathrm{pNZ8148- \textrm {HBcAg }}$

\begin{tabular}{l|c|c|c}
\hline \multicolumn{1}{c|}{ Sample } & $\mathrm{C}_{\mathrm{T}}$ of HBcAg gene & $\mathrm{C}_{\mathrm{T}}$ of $16 \mathrm{~S}$ rRNA gene & $\Delta \mathrm{C}_{\mathrm{T}}$ \\
\hline HBcAg uninduced & 6.73 & 3.89 & 2.85 \\
\hline $\mathrm{HBcAg}$ induced $5 \mathrm{ng} / \mathrm{ml}$ of nisin & 7.69 & 3.47 & 4.23 \\
\hline $\mathrm{HBcAg}$ induced $10 \mathrm{ng} / \mathrm{ml}$ of nisin & 8.37 & 3.32 & 5.05 \\
\hline $\mathrm{HBcAg}$ induced $50 \mathrm{ng} / \mathrm{ml}$ of nisin & 7.35 & 3.85 & 3.50 \\
\hline
\end{tabular}

$\mathrm{HBcAg}$ cassette and was subsequently transformed to $E$. coli MC1061 for use as a cloning host strain. The selection of transformants was undertaken on the basis of chloramphenicol resistance, PCR amplification (PNisA_F and TpNZ8148_R), and restriction enzyme analysis using Nco 1 and $X b a 1$. Recombinant pNZ8148-HBcAg from po- sitive transformants was purified and successfully transformed to L. lactis NZ3900, which was used as the expression host strain. The vector transformants were screened by PCR amplification (using PNisA_F and TpNZ8148_R primers) and digestion by Nco1 and Xba1 restriction enzymes. The pNZ8148-HBcAg recombinant 
vector was 3815 bp-long with a $630 \mathrm{bp}$-long HBcAg gene (Fig. 2). DNA sequence analysis of recombinant pNZ8148-HBcAg was conducted to determine the sequence of the inserted HBcAg gene (Fig. 3). DNA sequencing revealed that the recombinant cassette had no mutations. Moreover, a translation analysis showed there was no amino acid substitution in the protein sequence, and the recombinant vector carried the desired gene. HBcAg had an open reading frame of $549 \mathrm{bp}$ that encoded 183 amino acid residues with a predicted molecular weight of $21 \mathrm{kDa}$. The restriction analysis (Fig. 2) and DNA sequencing (Fig. 3) confirmed that the $\mathrm{HBcAg}$ gene had been successfully inserted into the pNZ8148 expression vector and transformed into $L$. lactis NZ3900.

\section{Verification of expression of HBcAg mRNA level}

The first step of the analysis was RNA isolation from the $L$. lactis culture that carried the recombinant pNZ8148-HBcAg plasmid induced with nisin. The highest RNA concentration was obtained when expression was induced with $50 \mathrm{ng} / \mathrm{ml}$ nisin $(172 . \mathrm{ng} / \mu \mathrm{l})$, whereas the lowest was observed in uninduced samples $(89.2 \mathrm{ng} / \mu \mathrm{l})$. The cDNA was synthesized from total RNA using reverse transcriptase. The highest $\mathrm{HBcAg} \mathrm{cDNA}$ concentration was obtained upon the induction of L. lactis $\mathrm{pNZ} 8148-\mathrm{HBcAg}$ with $50 \mathrm{ng} / \mathrm{ml}$ nisin. Subsequently, cDNA was used for qPCR, performed using a SYBR green kit and a pair of HBcAg BamHI-HindIII primers. The results are presented in Table 3 , and indicate successful expression of the HBcAg gene.

\section{Analysis of HBcAg protein expression}

The recombinant $\mathrm{HBcAg}$ protein was expressed in L. lactis NZ3900. The $21-\mathrm{kDa} \mathrm{HBcAg}$ protein was present in isolates from samples of recombinant $L$. lactis NZ3900 pNZ8148-HBcAg (Fig. 5). The protein was analyzed by Western blotting and dot blot hybridization using a purified monoclonal $\mathrm{HBcAg}$ antibody. The results indicate that recombinant pNZ8148-HBcAg protein $(21 \mathrm{kDa})$ was recognized and bound by the $\mathrm{HBcAg}$ antibody. However, in a sample derived from bacteria containing an empty vector, there was no antibody signal on the nitrocellulose membrane. Concentrations of total protein samples from different groups are shown in Table 5. The total protein level was found to be highest and significantly increased in samples grown with

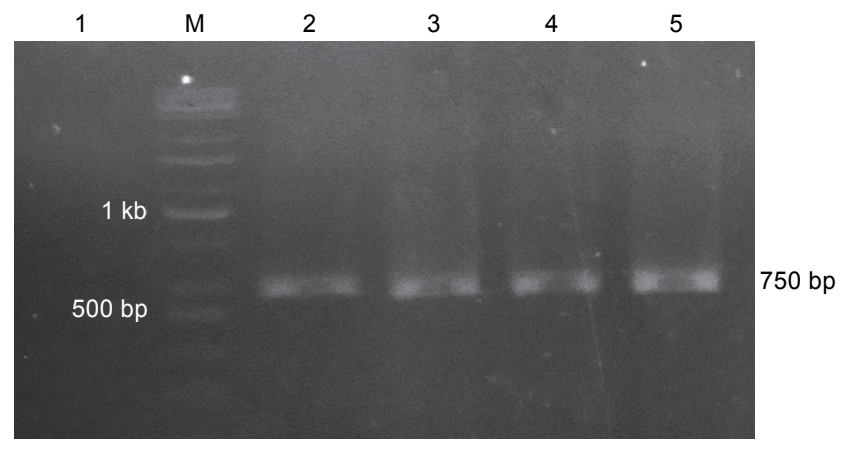

Fig. 4. The result of $\mathrm{HBcAg}$ cDNA amplification from total cDNA 1) L. lactis NZ3900 as negative control 2) L. lactis pNZ8148-HBcAg uninduced 3) induced by $5 \mathrm{ng} / \mathrm{ml}$ nisin 4) induced by $10 \mathrm{ng} / \mathrm{ml} \mathrm{nisin} \mathrm{5)} \mathrm{induced} \mathrm{by} 50 \mathrm{ng} / \mathrm{ml} \mathrm{nisin}$

40

25

15 $\leftarrow 21 \mathrm{kDa}$

10

4.8

1.7

Fig. 5. Western blotting analysis of a fraction sample after purification with size-exclusion chromatography; the band of $\mathrm{HBcAg}$ protein was identified at the $21 \mathrm{kDa}$ position

$10 \mathrm{ng} / \mathrm{ml}$ nisin $(11.852 \pm 0.182 \mathrm{mg} / \mathrm{ml})$, when compared with uninduced samples, or those with 5 or $50 \mathrm{ng} / \mathrm{ml}$ nisin. The level of protein expression was markedly increased by the addition of nisin to the growth media when compared with uninduced samples; however, the highest induction was observed for samples to which $10 \mathrm{mg} / \mathrm{ml}$ nisin was added. Bacteria containing an empty vector were used to measure the level of total protein expression; therefore, it was used for the quantification of basal protein in the recombinant sample. Estimation of $\mathrm{HBcAg}$ protein concentration in the recombinant sample was carried out by subtracting the total protein content of recombinant samples from the total protein content produced by cells containing an empty vector. 
Table 4. $\Delta \Delta \mathrm{C}_{\mathrm{T}}$ of induced of $L$. lactis pNZ8148-HBcAg

\begin{tabular}{l|c|c}
\hline \multicolumn{1}{c|}{ Sample } & $\Delta \Delta \mathrm{C}_{\mathrm{T}}$ & $\begin{array}{c}\text { Enhancement of protein } \\
\text { expression levels } \\
\text { between induced } \\
\text { and uninduced samples }\end{array}$ \\
\hline $\mathrm{HBcAg}$ induced $5 \mathrm{ng} / \mathrm{ml}$ of nisin & 1.38 & $2.60 \times$ \\
\hline $\mathrm{HBcAg}$ induced $10 \mathrm{ng} / \mathrm{ml}$ of nisin & 2.20 & $4.59 \times$ \\
\hline $\mathrm{HBcAg}$ induced $50 \mathrm{ng} / \mathrm{ml}$ of nisin & 0.65 & $1.57 \times$ \\
\hline
\end{tabular}

Table 5. Concentration of protein expression of total fractions in recombinant cells containing the HBcAg-expressing vector

\begin{tabular}{l|c}
\hline \multicolumn{1}{c|}{ Samples } & Total protein $[\mathrm{mg} / \mathrm{ml}]$ \\
\hline Empty vector (L. lactis pNZ8148) & $5.316 \pm 0.249$ \\
\hline HBcAg uninduced & $6.760 \pm 0.902$ \\
\hline HBcAg induced $5 \mathrm{ng} / \mathrm{ml}$ of nisin & $7.109 \pm 0.162$ \\
\hline HBcAg induced $10 \mathrm{ng} / \mathrm{ml}$ of nisin & $11.852 \pm 0.182$ \\
\hline HBcAg induced $50 \mathrm{ng} / \mathrm{ml}$ of nisin & $8.950 \pm 0.490$ \\
\hline
\end{tabular}

\section{Discussion}

The $\mathrm{HBcAg}$ protein has been used as a therapeutic vaccine because it can induce strong $\mathrm{B}-\mathrm{-}, \mathrm{T}$-, and cytotoxic T-cell proliferation (Chisari and Ferrari, 1995). In addition, the HBcAg protein can induce an immune response and provide immunogenicity against HBV (Freivalds et al., 2011). Here, we report the construction and expression of $\mathrm{HBcAg}$ in L. lactis. This study is the first research on the expression of $\mathrm{HBcAg}$ proteins using $L$. lactis as the host. The HBcAg gene was designed according to the HBcAg nucleotide sequence of the dominant HBV subgenotype in Indonesia. Sugauchi et al. (2008) reported that the HBV B2 substrain (HBV/B2) was discovered mostly in Indonesians of Chinese ethnic origin, and HBV/B3 was dominant among the Javanese, who constitute the largest ethnic group. Thus, the protein so obtained can be used to produce an HBV vaccine that has high compatibility and, therefore, the potential ability to prevent HBV infection in Indonesia. The $\mathrm{HBcAg}$ protein is a dimer and forms Cys61-Cys61 disulfide bonds connecting the two monomers (Zlotnick et al., 2012). In addition to its capability of being generated in recombinant $E$. coli, the $\mathrm{HBcAg}$ protein can be assembled into core virus particles within prokaryotic and eukaryotic hosts (Schodel et al., 1992). In this work, we produced for the first time an HBcAg protein in recombinant $L$. lactis NZ3900 by utilizing the inducible
NICE system promotor. Lactococcus lactis NZ3900 is a strain derived from L. lactis NZ9000 that is commonly used in food-grade products and biopharmaceutical industries. From a cluster of nisin genes, the nis $K$ and $n i s R$ signals transduction genes were isolated and inserted into L. lactis subsp cremoris MG1363 to produce L. lactis NZ9000 (Mierau et al., 2005). These signal transduction genes are used to induce protein expression in the NICE system because it comprises the nis operon ( $P$ nisA as a nisin-inducible promotor) and nis RK (sensor of regulatory function). The addition of nisin into a culture medium is detected by NisK, which induces its autophosphorylation. Furthermore, a phosphate group is transferred to Nis R which then activates transcription (Platteeuw et al., 1996). The addition of a signal peptide $\left(\mathrm{SP}_{\text {usp } 45}\right)$ to the coding sequence causes the HBcAg protein to be secreted extracellularly. This signal peptide is generally utilized for heterologous protein production in L. lactis and is commonly fused with the inducible NICE system (Le Loir et al., 1998; Mierau et al., 2005; Novotny et al., 2005). The usp 45 gene encodes a major extracellular protein in L. lactis (Dieye et al. 2001).

This system has been used to produce high levels of recombinant Plantaricin $\mathrm{W}(\mathrm{Pln} \mathrm{W})$ protein in L. lactis, and maximum expression of recombinant $\mathrm{PlnW}$ was obtained by induction with $50 \mathrm{ng} / \mathrm{ml}$ nisin (Lages et al., 2015). In the present research, induction with $10 \mathrm{ng} / \mathrm{ml}$ nisin ge- 
nerated the highest $\mathrm{HBcAg}$ protein expression, which was further confirmed by immunoblotting and concentration of the total protein fraction (Table 5 and Fig. 5).

This workrevealed that recombinant L. lactis NZ3900 pNZ8148-HBcAg can produce HBcAg. The qPCR data analysis was conducted to confirm the production of $\mathrm{HBcAg}$ mRNA. The qPCR uses the $\mathrm{C}_{\mathrm{T}}$ comparison method $\left(\Delta \Delta \mathrm{C}_{\mathrm{T}}\right.$ method) to calculate the difference between the $\mathrm{C}_{\mathrm{T}}$ values $\left(\Delta \mathrm{C}_{\mathrm{T}}\right)$ of a desired gene (from each induction treatment) and the housekeeping gene (16s rRNA) to find the expression level of the $\mathrm{HBcAg}$ gene. The $\Delta \mathrm{C}_{\mathrm{T}}$ of L. lactis pNZ8148-HBcAg induced by $10 \mathrm{ng} / \mathrm{ml}$ nisin generated the highest output when compared to that of induction with 0.5 and $50 \mathrm{ng} / \mathrm{ml}$ nisin. Comparison of the fold-change in the expression level of the induced and uninduced samples revealed that induction with $10 \mathrm{ng} / \mathrm{ml}$ nisin had the highest fold-change (4.59×).

Protein identification was confirmed by Western blotting, as it was recognized by the monoclonal $\mathrm{HBcAg}$ antibody. A DNA sequencing analysis showed there was no mutation in the coding sequence. A translational analysis showed that the recombinant protein has no amino acid substitution. Purification of the $\mathrm{HBcAg}$ protein with size-exclusion successfully produced a band of protein in the $21-\mathrm{kDa}$ position on Western blotting analysis.

\section{Conclusions}

The recombinant L. lactis pNZ8148-HBcAg genic sequence was successfully constructed and expressed in L. lactis NZ3900 by using the NICE system. The highest HBcAg expression level was achieved by the addition of $10 \mathrm{ng} / \mathrm{mL}$ nisin to the culture medium. Proteins were detected using a specific $\mathrm{HBcAg}$ antibody in Western blotting and dot blot hybridization assays. The results of the study could facilitate $\mathrm{HBcAg}$ protein production in $L$. lactis and has the potential to form the basis for an HBV therapeutic vaccine.

\section{Acknowledgments}

This study was supported by the Program Unggulan LIPI 2017 and Program Nasional Obat 2018 of the Indonesian Institute of Science (LIPI) and Indonesia Endowment Fund for Education (LPDP).

\section{References}

Azizi M., Musacchio A., Pardo O., Figueroa N., Muzio V. (2000) Expression of Hepatitis B Virus Core Antigen in native and fusion forms in E. coli. J. Iran. Biomed. 4: 37-43.
Bermudez-Humaran LG., Kharrat P., Chatel J.M., Langella P. (2011) Lactococci and lactobacilli as mucosal delivery vectors for therapeutic proteins and DNA vaccines. Microb. Cell Fact. 10 (Suppl 1): S4.

Bertoletti A., Ferrari C. (2012) Innate and adaptive immune responses in chronic hepatitis $B$ virus infections: towards restoration of immune control of viral infection. J. Gut. 61: 1754-1764.

Buchmann P., Dembek C., Kuklick L., Jäger C., Tedjokusumo R., Freyend M.J., Drebber U., Janowicz Z., Melber K., Protzer U. (2013) A novel therapeutic hepatitis $B$ vaccine induces cellular and humoral immune responses and breaks tolerance in hepatitis $B$ virus ( $H B V$ ) transgenic mice. Vaccine. 31: 1197-1203.

Chisari F.V., Ferrari C. (1995) Hepatitis $B$ virus immunopathogenesis. Annu. Rev. Immunol. 13: 29-60.

Dieye Y., Usai S., Clier F. (2001) Design of a protein targeting system for lactic acid bacteria. J. Bacteriol. 183: 4157-4166.

Freivalds J., Dislers A., Ose V., Pumpens P., Tars K., Kazaks A. (2011) Highly efficient production of phosphorylated hepatitis $B$ core particles in yeast Pichia pastoris. Protein. Expr. Purif. 75: 218-224.

Heriyanto D.S., Yano Y., Utsumi T., Anggorowati N., Rinonce H.T., Lusida M.I., Soetjipto., Triwikatmani C., Ratnasari N., Maduseno S. (2012) Mutations within enhancer II and $B C P$ regions of hepatitis $B$ virus in relation to advanced liver diseases in patients infected with subgenotype B3 in Indonesia. J. Med Virol. 84: 44-51.

Holo H., Nes I.F. (1995) Transformation of Lactococcus by electroporation. Meth. Mol Biol. 47: 195-199.

Hong P., Koza S., Bouvier E.S.P. (2012) A review size-exclusion chromatography for the analysis of protein biotherapeutics and their aggregates. J. Liq. Chromatogr. Relat. Technol. 35: 2923-2950.

Jorgensen C.M., Vrang A., Madsen S.M. (2014) Recombinant protein expression in Lactococcus lactis using the P170 expression system. FEMS Microbial. Lett. 351: 170-178.

Lages A.C., Mustopa A.Z., Sukmarini L., Suharsono S. (2015) Cloning and expression of Plantaricin $W$ produced by Lactobacillus plantarum U10 isolate from "Tempoyak" Indonesian fermented food as immunity protein in Lactococcus lactis. Appl. Biochem. Biotechnol. 177: 909-922.

Le Loir Y., Gruss A., Ehrlich S.D., Langella P. (1998) A nineresidue synthetic propeptide enhances secretion efficiency of heterologous proteins in Lactococcus lactis. J. Bacteriol. 180: 1895-1903.

Lusida M.I., Nugrahaputra V.E., Soetjipto R., Nagano-Fujii M., Sasayama M., Utsumi T., Hotta H. (2008) Novel subgenotypes of hepatitis $B$ virus genotypes $C$ and D in Papua, Indonesia. J. Clin. Microbiol. 46: 2160-2166.

Mierau I., Olieman K., Mond J., Smid E.J. (2005) Optimization of the Lactococcus lactis nisin-controlled gene expression system NICE for industrial applications. Microb. Cell. Fac. 4: 16

Maini M.K., Boni C., Lee C.K., Larrubia J.R., Reignat S., Ogg G.S, King A.S., Herberg J., Gilson R., Alisa A., et al. (2000) The role of virus-specific CD8(+) cells in liver damage and 
viral control during persistent hepatitis $B$ virus infection. J. Exp. Med. 191: 1269-1280.

Novotny R., Scheberl A., Giry-Laterriere M. (2005) Gene cloning, functional expression and secretion of the Slayer protein $S g s E$ from Geobacillus stearothermophilus NRS 2004/3a in Lactococcus lactis. FEMS Microbiol. Lett. 242: 27-35.

Platteeuw C., van Alen-Boerrigter I., van Schalkwijk S., de Vos V.M. (1996) Food-grade cloning and expression system for Lactococcus lactis. Appl. Environ. Microbiol. 62: 1008-1013.

Rajalingam D., Loftis C., Kumar T.K.S. (2009) Trichloroacetic acid-induced protein precipitation involves the reversible association of a stable partially structured intermediate. Protein Sci. 18: 980-993.

Rolland D., Gauthier V., Dugua J.M., Fournier C., Delpech L., Watelet B., Letourneur O., Arnaud M., Jolivet M. (2001) Purification of recombinant $\mathrm{HBC}$ antigen expressed in Escherichia coli and Pichia pastoris: comparison of sizeexclusion chromatography and ultracentrifugation. J. Chromatogr B. 753: 51-65.

Sambrook J., Russell D.W. (2001) Molecular cloning: a laboratory manual. New York: 3rd ed. Cold Spring Harbor Laboratory Press.
Schodel F., Peterson D., Zheng J., Jones J.E., Hughes J.L., Milich D.R. (1992) Structure of Hepatitis B virus core and e-antigen. J. Bio. Chem. 268: 1332-1337.

Sugauchi F., Orito E., Ichida T., Kato H., Sakugawa H., Kakumu S., Ishida T., Chutaputti A., Lai., Ueda R., et al. (2002) Hepatitis $B$ virus of genotype $B$ with or without recombination with genotype $C$ over the precore region plus the core gene. J. Virol. 76: 5985-5992.

Utsumi T., Lusida M.I., Yano Y., Nugrahaputra V.E., Amin M., Juniastuti Y., Soetjipto., Hayashi Y., Hotta H. (2009) Complete genome sequence and phylogenetic relatedness of hepatitis $B$ virus isolates in Papua, Indonesia. J. Clin. Microbiol. 47: 1842-1847.

WHO (2015) Global Hepatits Report, 2017. Full report WHO. ISBN: 978-92-4-156545-5

Wingfield P.T., Stahl J.S., Williams R.W., Steven A.C. (1995) Hepatitis Core Antigen Produce in E. coli: subunit compotition, conformational analysis and in vitro capsid assembly. J. Biochem. 34: 4919-4932.

Zlotnick A., Tan Z., Selzer L. (2013) One protein, at least three structures, and many functions. Structure 21: 6-8. 